No. 2(71), 2021, pp.203-224

\author{
Malia Lee Womack (D) \\ The Ohio State University \\ malia.lee.womack@gmail.com
}

\title{
MILITARIZING HATE, PERPETUATING VIOLENCE AND RAPE, AND ALLOWING HUMAN RIGHTS ABUSES TO GO UNPUNISHED
}

ABSTRACT The United States does not comply with the International Convention on the Elimination of All Forms of Racial Discrimination (ICERD), which is the United Nations' core binding anti-racism human rights convention. One hundred and seventy seven states, including the US, have ratified the anti-racism multilateral agreement. The nation entered into the pact in 1994 yet still has not implemented its obligations to the statute. This study focuses on the protections ICERD provides Latino immigrants who are not United States citizens as this group is often ignored in advocacy for implementation strategies. Areas where the United States does not comply with ICERD include discriminatory immigration policies and practices, violent and discriminatory policing, gendered violence, and inequalities in the criminal justice system. It is critical to examine ICERD's protections for Latino non-citizens because it reveals how the group experiences racism differently than other people because they endure intersectional forms of systematic and institutional discrimination due to their race, ethnicity, citizenship status, gender, and other identity traits. Methodologies used in this study include analysis of ICERD's monitoring body's General Recommendations, and the monitoring body's reports about the United States' lack of compliance with the statute. These are the most powerful regulatory forces of the treaty due to the monitoring body's positionality as experts about the pact appointed through the United Nations system.

Keywords: immigration, institutional racism, militarized policing, gendered violence, intersectionality 
The protesters in New Mexico were thugs who were flying the Mexican flag. The rally inside was big and beautiful, but outside, criminals!

When Mexico sends itspeople, they're not sending their best. They're not sending you. They're not sending you. They're sending people that have lots of problems, and they're bringing those problems with us. They're bringing drugs. They're bringing crime. They're rapists.

I did try and fuck her. (...) I moved on her like a bitch. (...) Then all of the sudden I see her, she's now got the big phony tits. (...) Look at you, you are a pussy. (...) I'm automatically attracted to beautiful - I just start kissing them. It's like a magnet. Just kiss. I don't even wait. And when you're a star, they let you do it. You can do anything. (...) Grab 'em by the pussy. You can do anything.

Donald Trump

Donald Trump, the United States' 2016 president elect, received widespread media attention due to stereotyping Latino immigrants as criminals and rapists and also due to bragging about predatorily sexually assaulting women and trivializing it as if it were mundane male behavior. How was it possible for a man of this nature to become the forty-fourth president of the United States (US)? When examining the nation's systematic and institutional human rights abuses conducted against women and Latino immigrants, it is clear that his election to office is reflective of hegemonic ideologies in the nation that devalue women's and Latinos' worth.

This paper explores how the United States does not comply with the International Convention on the Elimination of All Forms of Racial Discrimination (ICERD), ${ }^{1}$ which is the United Nations' core binding anti-racism human rights convention. One hundred and seventy seven states, including the United States, have ratified the antiracism multilateral agreement. The nation entered into the pact in 1994 yet still has not implemented its obligations to the statute. This study focuses on the protections ICERD provides Latino immigrants who are not United States citizens as this group is often ignored in advocacy for implementation strategies. Areas where the United States does not comply with ICERD include discriminatory immigration policies and practices, violent and discriminatory policing, gendered violence, and inequalities in the criminal justice system. It is critical to examine ICERD's protections for Latino noncitizens because it reveals how the group experiences racism differently than other people because they endure intersectional forms of systematic and institutional discrimination due to their race, ethnicity, citizenship status, gender, and other identity traits. Methodologies used in this study include analysis of ICERD's monitoring body's General Recommendations, and the monitoring body's reports about the United States' lack of compliance with the statute. These are the most powerful regulatory forces of the treaty due to the monitoring body's positionality as experts about the pact appointed through the United Nations system.

The preamble and Part I of the treaty are included in Appendix A of this paper. 


\section{THE UNITED STATES’ RESISTANCE TO ICERD}

When states become members to human rights treaties they can modify the treaties with reservations, understandings, and declarations (RUDs) which prevents the states from being bound to particular articles in the statutes. RUDs are discouraged by human rights treaties' monitoring bodies, however they are permitted (as long as they do not conflict with the purpose of the treaty in question) in order to encourage the largest number of states to become parties to the pacts. When the United States became a member of ICERD it modified the treaty with a spectrum of RUDs. Anytime the government sanctions human rights multilateral agreements, it enters into more RUDs than any other developed country. ${ }^{2}$ US courts enforce the modifications, however there is concern that the government overuses these provisions. ${ }^{3}$ Modifications the nation submitted when it entered into ICERD include RUDs that protect federalism, sovereignty, privacy, and freedom of speech. Three reservations were included, one which protects freedom of expression, speech, and association, another which limits government interference with private conduct, and a third which prohibits the International Criminal Court from interfering with US operations without the state's consent. One understanding declares the government will only implement the treaty to the extent that its federal jurisdiction allows. Finally, the state submitted a declaration that the treaty is not self-executing, which was premised on the belief that the United States' domestic laws and policies adequately address and provide remedies for racial discrimination. ${ }^{4}$ However, the UN's Human Rights Committee criticizes that this declaration is in direct violation with the object and purpose of the pact. ${ }^{5}$ Moreover, according to Article VI of the United States' Constitution, when treaties are ratified they must become the "supreme law of the land," thus the declaration is also in conflict with the nation's constitution. ${ }^{6}$ Nevertheless, the United States alleges that it fully complies with the multilateral agreement due to these modifications and due to the government's legislation and policies enacted prior to entering into the pact. There are mechanisms in place to police this standpoint.

Every two years ICERD's members are required to submit a report to the treaty's monitoring body about their compliance with the multilateral agreement. The United

\footnotetext{
A. Moravcsik, The Paradox of US Human Rights Policy, in M. Ignatieff(ed.), American Exceptionalism and Human Rights, Princeton 2005, pp. 147-197.

3 E. Chung, "The Judicial Enforceability and Legal Effects of Treaty Reservations, Understandings, and Declarations", The Yale Law Journal, vol. 126, no. 170 (2016), pp. 170-224.

4 L. Herndon, "Why Is Racial Injustice Still Permitted in the United States? An International Human Rights Perspective on the United States' Inadequate Compliance with the International Convention on the Elimination of all Forms of Racial Discrimination", Wisconsin International Journal of Law, vol. 31, no. 2 (2013), pp. 323-351.

5 Ibid.

6 H. Harris, "Race Across Borders: The US and ICERD”, Harvard BlackLetter Law Journal, vol. 24, no. 1 (2008), pp. 61-67; L. Herndon, "Why is Racial Injustice..."
} 
States has not fulfilled its obligation to submit these reports in the required timespan. In fact, since the government became a member to the pact in 1994 it has only submitted reports two of the ten times it was required to within the given timespan. The first report was submitted in 2007, ten years after it was due. It was sorely lacking in its assessment of race in the United States, and much of it was cut and pasted from previous reports the United States submitted about other conventions. ${ }^{7}$ Race was not mentioned at all in some sections. ${ }^{8}$ Also, one year after adoption of the treaty, state parties are required to submit a report about their compliance with the multilateral agreement. The United States did not submit this report until the year 2000, which is five years past when it was due. ${ }^{9}$ This lack of commitment with complying with the reporting process mirrors the government's lack of will to meet its obligations to the pact. The 2000 report asserted that the United States' laws, policies, and practices fully comply with the multilateral agreement including related to discrimination due to national origin, gender, and citizenship status. ${ }^{10}$ In contrast to this assertion, this paper reveals how the United States does not fulfill its duties to ICERD in regard to the treaty's mandates about immigration policies and practices, violent and discriminatory policing, gendered violence, and criminal justice procedures.

\section{EXAMINING HUMAN RIGHTS THROUGH AN INTERSECTIONAL LENS}

ICERD's expert committee informs that intersectionality must be addressed in strategies to implement the multilateral agreement. ${ }^{11}$ In the United States, non-citizen Latinos are subject to a multiplicity of oppressions due to their intersectional identities. It is critical to examine the statute from an intersectional perspective in order to advocate for implementation strategies that do not treat the experiences of people of color in a monolithic manner. This results in privileging the needs of groups with more power (such as male citizens) while marginalizing the needs of groups with less power (such as female non-citizens). Intersectional theory addresses 'multidimensionality' or 'multiple forms of discrimination' that individuals experience due to their compounded identity traits. ${ }^{12}$ Discrimination an individual experiences due to their citizenship status (or perceived citizenship status) is compounded by other discrimination and abuse they expe-

\footnotetext{
H. Harris, Race Across Borders...

8 Ibid.

9 US Department of State, "Committee on the Elimination of Racial Discrimination (CERD) Report", US Department of State 2017, at <www.state.gov/j/drl/rls/cerd_report/>, 15 March 2017.

10 US Department of State, "Reports Submitted by States Parties Under Article 9 of the Convention", United Nations 2000.

11 H. Lewis, “Transnational Dimensions of Women's Empowerment: Refocusing on Economic, Social, and Cultural Rights", Northeastern University School of Law: School of Law Faculty Publications 2010, pp. 1-10. 
rience such as sexism. ${ }^{13}$ Categories of identity within one human subject do not merely intersect; they mutually constitute one another. ${ }^{14}$ Furthermore, identity traits such as immigration status, race, ethnicity, religion, class, and gender, are historically formed and shaped by power structures such as heterosexism, global capitalism, patriarchy, colonialism, neocolonialism, imperialism, neoliberalism, and globalization. ${ }^{15}$ Through these systems of power Latino immigrants have hegemonically been classified as inferior residents in the United States. Citizenship is systematically regulated by the US government in a manner that constructs a national futurity that concretizes and reproduces middle to upper class white male domination on the nation's resources. The most privileged members of the nation commonly object to rights that challenge state institutions, whiteness, and the global capitalist concentration of wealth and power. ${ }^{16}$

Why then, for example, do Latina women immigrate to the nation? Although women traditionally [immigrated] under the auspices of family reunification schemes, the past four decades have witnessed significant transformations in the trends offemale migration. ${ }^{17}$ Women today often immigrate as independent economic actors. ${ }^{18}$ The United States is an economic superpower in the world economy, and as such its residents benefit from the wealth of resources in the nation (however unevenly these resources are distributed). For the most part, these women have made independent, voluntary decisions to move abroad in order to escape poverty, hardship or persecution and ultimately to improve their own situation, and that of their families. ${ }^{19}$ Despite these aspirations, immigration frequently leads to new forms of disempowerment, abuse and exploitation. ${ }^{20}$

Since the United States became a state in the $18^{\text {th }}$ century it constructed a concept of rights based on citizenship and national sovereignty rather than the protection of

13 A. Edwards, Displacement, Statelessness, and Questions of Gender Equality and the Convention on the Elimination of All Forms of Discrimination Against Women, 2009, at <http://www2.ohchr.org/English/bodies/cedaw/docs/UNHCR_CEDAW_Background_Paper4.pdf>, 15 March 2017.

14 F. Cooper, “'Who's the Man?' Masculinities Studies, Terry Stops, and Police Training”, Columbia Journal of Gender and Law, vol. 18, no. 3 (2008), pp. 671-742.

15 M. Lugones, "Heterosexualism and the Colonial/Modern Gender System", Hypatia, vol. 22, no. 1 (2007), pp.186-209; M.J. Alexander, C.H. Mohanty, "Cartographies of Knowledge and Power: Transnational Feminism as Radical Praxis”, in A. Lock Swarr, R. Nagar (eds.), Critical Transnational Feminist Practice, New York 2010, pp. 23-45.

16 A. Agathangelou, D. Olwan, T.L. Spira, H. Turcotte, "Sexual Divestments from Empire: Women's Studies, Institutional Feelings, and the 'Odious' Machine”, Feminist Formations, vol. 27, no. 3 (2015), pp. 139-167.

17 A. Gillespie, Shipping away the Victims and Passing on the Burdens: Can States Continue to Disregard Gender-Based Violence against Women Migrants on the Basis of Their Immigration Status?, 2008, at $<$ http://s3.amazonaws.com/academia.edu.documents/31719996/Aoife_Gillespie_LLM_Dissertation.pdf ?AWSAccessKeyId=AKIAIWOWYYGZ2Y53UL3A\&Expires=1489723250\&Signature $=$ ArJbV8HuYrR1 Ucw18YpP6HAas\%2FM\%3D\&response-content disposition=inline\%3B\%20 filename\%3DShipping_Away_the_Victims_and_Passing_on. Pdf>, 1 February 2021.

18 Ibid.

19 Ibid.

20 Ibid. 
humanity. ${ }^{21}$ This continued in the $19^{\text {th }}$ century when, similar to the previous century, rights protected predominantly white males while subjecting women, non-citizens, indigenous people, and men of color to exploitation and violence. White citizens consumed the native race[s], fomented and lived off slavery (...) and reduced or robbed the neighboring countries [yet] believed in the invincible superiority of 'the Anglo-Saxon race. ${ }^{22}$ In the 1800 s what was coined the rights of man was based on the propagation of national sovereignty and a racist and sexist notion of citizenship. ${ }^{23}$ When the United Nations was founded in 1945, the United States remained committed to protecting US sovereignty and advancing the US empire. ${ }^{24}$ By the late 1900 s the rise of the new international space occurred in tandem with the burgeoning of a more chauvinistic brand of [US] nationalism. ${ }^{25}$ Throughout history and currently, living in the United States means living under laws and institutions that exploit and subjugate people of color within US borders and transnationally. ${ }^{26}$

ICERD addresses citizenship. The treaty's preamble asserts that all humans are entitled to all the rights and freedoms dictated within the pact, without distinction of any kind, in particular as to race, colour or national origin. ICERD's Article 5 requires member states to prohibit and eliminate racial discrimination in all its forms and guarantee the right of everyone, without distinction as to race, colour, or national or ethnic origin, to equality before the law. ICERD's committee's General Recommendation 30 emphasizes that states must ensure that legislative guarantees against racial discrimination apply to noncitizens regardless of their immigration status, and that the implementation of legislation does not have a discriminatory effect on non-citizens. General Recommendation 30 also contends that buman rights are, in principle, to be enjoyed by all persons. States parties are under an obligation to guarantee equality between citizens and non-citizens in the enjoyment of these rights to the extent recognized under international law. The expert committee also requires member states to collect gender disaggregated data about legislation and non-citizenship and report it to the expert body. General Recommendation 25 recognizes that racial discrimination affects women differently than men in a variety of ways and that there are circumstances in which racial discrimination only or primarily affects women, or affects women in a different way, or to a different degree than men. General Recommendation 25 notes that such racial discrimination will often escape detection if there is no explicit recognition or acknowledgement of the different life experiences of women and men, in areas of both public and private life. General Recommendation 32 insists member states must examine racial

21 S. Moyn, The Last Utopia: Human Rights in History, Cambridge 2010.

22 M. Lake, H. Reynolds, Drawing the Global Colour Line: White Men's Countries and the International Challenge of Racial Equality, Cambridge 2008.

23 S. Moyn, The Last Utopia...

24 Ibid.

25 Ibid.

26 C. Higashida, "Audre Lorde Revisited: Nationalism and Second-Wave Black Feminism", in eadem (ed.), Black Internationalist Feminism: Women Writers of the Black Left, 1945-1995, 2011, Champaign 2011, pp. 134-157. 
discrimination with the notion of 'intersectionality' to acknowledge situations of double or multiple discrimination.

Despite the above requirements, ICERD's Article 1.3 clarifies that the multilateral agreement should not be interpreted as affecting in any way the legal provisions of States Parties concerning nationality, citizenship or naturalization, provided that such provisions do not discriminate against any particular nationality. Article 1 of the pact defines racial discrimination as any distinction, exclusion, restriction or preference based on race, colour, descent, or national or ethnic origin which has the purpose or effect of nullifying or impairing the recognition, enjoyment or exercise, on an equal footing, of human rights and fundamental freedoms in the political, economic, social, cultural or any other field of public life. General Recommendation 11 clarifies ICERD excepts from this definition actions by a State party which differentiate between citizens and non-citizens. However, General Recommendation 30 advises that differential treatment based on citizenship or immigration status will constitute discrimination if the criteria for such differentiation, judged in the light of the objectives and purposes of the Convention, are not applied pursuant to a legitimate aim, and are not proportional to the achievement of this aim. As the pages that follow delineate, ICERD's monitoring body identifies the ways in which US policies regarding Latino non-citizens are in many ways not designed with a legitimate aim.

\section{THE EXPANSION OF MILITARIZED INSTITUTIONAL INEQUALITIES}

What protections does ICERD provide Latinos who are not US citizens in regard to equal treatment in courts and justice administering organizations? ICERD's Article 2.1.a mandates state parties must engage in no act or practice of racial discrimination against persons, groups of persons or institutions and ensure that all public authorities and public institutions, national and local, shall act in conformity with this obligation. Article 2.1.c requires that member states must take effective measures to review governmental, national and local policies, and amend, rescind or nullify any laws and regulations which have the effect of creating or perpetuating racial discrimination. ICERD's Article 5.a requires that regardless of national or ethnic origin, all residents in state parties to the convention must have the right to equal treatment before the tribunals and all other organs administering justice. General Recommendation 20 reaffirms that many of the rights and freedoms mentioned in [A]rticle 5 , such as the right to equal treatment before tribunals, are to be enjoyed by all persons living in a given State. Moreover, General Recommendation 30 delineates that non-citizens should not be subject to arbitrary detention, that deportation should not be conducted in manners that discriminate on the basis of race, colour or ethnic or national origin, and that members to the convention avoid expulsions of non-citizens, especially of long-term residents, that would result in disproportionate interference with the right to family life. The expert body requires member states to justify immigration detention; justifications outlined include risk of 
flight, risk that the person might destroy evidence or influence witnesses or risk of serious disturbance of public order. ${ }^{27}$

No international treaty solely focuses on the human rights of people who are in immigration detention. ${ }^{28}$ However, as highlighted above, ICERD clearly provides protections to people detained due to discriminatory immigration policies. In contrast to these protections, Congress has (1) increased the number of immigration-related criminal offenses as well as the severity of punishment, (2) expanded the number of criminal offenses that require deportation, and (3) delegated more immigration enforcement to state and local law enforcement officers. ${ }^{29}$ Prior to 1929 immigration violations were civil offences. ${ }^{30}$ In 1929, illegal entry into the United States became a misdemeanor and unsanctioned re-entry became a felony. ${ }^{31}$ Implementation of the 1986 Immigration Reform and Control Act further increased the amount of criminal offenses related to immigration. ${ }^{32}$ Policies that followed increased the severity of fines and the imprisonment length for existing immigration-related crimes. ${ }^{33}$

For example, the maximum prison sentence for persons who unlawfully re-enter the United States following deportation increased from two years to twenty years. (...) Immigration-related prosecutions quadrupled from 1996 to 2006, accounting for more than thirty percent of all federal prosecutions and constituting the single largest category of federal prosecutions. ${ }^{34}$

As of 1988 detention during deportation became mandatory. ${ }^{35}$ In 1994 the Immigration and Naturalization Services (INS) deported 45,674 non-citizens of which 32,512 had criminal convictions in the United States. ${ }^{36}$ This number increased rapidly by 2009 , when the INS deported 393,289 non-citizens, of which 128,345 had criminal convictions in the US. ${ }^{37}$ From 1994 to 2008 the population of non-citizens in detention increased by approximately six times, and approximately sixty eight percent of those detained were held in state, local, or for-profit private jails. ${ }^{38}$ Operation Streamline, founded in 2005, permits undocumented immigrants to be subject to mass hearings of groups up to eighty people at a time; people within each group must answer

27 M. Grange, I. Majcher, When Is Immigration Detention Lawful? The Monitoring Practices of UN Human Rights Mechanisms, Global Detention Project 2017.

$37 \quad$ Ibid.

38 Ibid. 
questions together and enter their pleas without adequate legal counsel..$^{39}$ ICERD's monitoring body expressed heightened concern about Operation Streamline and advises the United States to abolish the program. ${ }^{40}$

Immigrants in detention often endure human rights violations, emotional and physical abuse, inhumane living conditions, and inadequate healthcare, all of which have led to more than one hundred deaths of immigrant detainees since $2003 .{ }^{41} \mathrm{Im}$ migrants in detention generally wear the same prison garb as criminal inmates, eat the same food, have the same limited access to recreation and fresh air, and speak to their visitors through the same Plexiglas-encased video monitors. ${ }^{42}$ Many detainees are placed in the general criminal population of jails, which further heightens their risk of bodily, mental, and/or emotional harm. ${ }^{43}$ Children apprehended by ICE are also subject to human rights abuses, improper medical care, and inadequate legal representation. ${ }^{44}$ An array of nonprofits have criticized the poor conditions in which immigrants are detained, including the facilities' deficiencies in medical care, for example in relation to pregnancy, mental health, and specialized treatment for those in need due to different illnesses. ${ }^{45}$

Since 2003 more than 48,000 asylum seekers have been detained despite the fact many of them were found credible about their assertions that they faced a threat of persecution if they returned to their country of origin. ${ }^{46}$ Detention increases the anxiety and fear asylum seekers experience. The overwhelming majority of immigrants arrested, detained, and deported by ICE are Latinos. ${ }^{47}$ In contrast to the United States' obligations under ICERD, people detained for immigration do not have the privilege against self-incrimination, and do not have the right to public counsel at the government's expense. ${ }^{48}$

The militarization of immigration policies and practices generates heightened fear of deportation among Latino immigrants. Such fear has proven to create stress in regard to familial suffering and conflict, suffering among friendships, difficulty finding and maintaining employment, and has proven to decrease confidence in police capabilities to serve and protect, decrease confidence that Latino's will be treated

39 D. Becerra, "Anti-immigration Policies and Fear of Deportation: A Human Rights Issue", Journal of Human Rights and Social Work, vol. 1, no. 1 (2016), pp. 109-119.

40

41 Ibid.

42 B. Frey, K. Zhao, "The Criminalization and the International Norm of Non-Discrimination: Deportation and Detention in U.S. Immigration Law", Law and Inequality: A Journal of Theory and Practice, vol. 29, no. 2 (2011), pp. 279-312.

43 Ibid.

44 D. Becerra, Anti-immigration Policies and Fear of Deportation...

45 B. Frey, and K. Zhao, The Criminalization of Immigration...

46 Ibid.

47 D. Becerra, Anti-immigration Policies and Fear of Deportation...

48

B. Frey, and K. Zhao, The Criminalization of Immigration... 
fairly in US courts, and decrease confidence in the prospects for improved living conditions. ${ }^{49}$

The 1996 Illegal Immigration Reform and Immigrant Responsibility Act provides states the ability to access Immigration and Customs Enforcement databases and independently investigate and spearhead proceedings for removal..$^{50}$ Over seventy state or local law enforcement agencies in over twenty five states have taken advantage of this opportunity, yet the most alarming and controversial mandate spurring from this resource is Arizona's S.B.1070, which mandates police to verify the immigration status of people when they are stopped lawfully by police, when they are detained, or when they are arrested. ${ }^{51}$ The law allows state and local law enforcement officers to consider race, color, or national origin to request proof of immigration status from individuals they suspect may be undocumented. ${ }^{52}$ There are around six million people living in Arizona and approximately two million of the states' residents are Latino. ${ }^{53}$ As of 2010 six other states designed policies replicating Arizona's S.B.1070..$^{54}$

Families are also in jeopardy. Immigration officials and judges are required to enforce immigration policies without regard for the impact on spouses, partners, children, or other family members, which produces trauma and separates families. ${ }^{55}$ An estimated one million innocent spouses and minor children 'have been separated from [their] loved ones [because of] deportations on criminal grounds since 1997.' More than seventy percent of the non-citizens deported 'were expelled from the United States for non-violent offenses. ${ }^{56}$ Many non-citizen parents have children who were born in the United States and thus awarded citizenship. When these parents face deportation they must choose between leaving their children in the United States or bringing them with them when being deported. ${ }^{57}$ In many cases children participate in this stressful decision-making process. This sense of fear and uncertainty impacts the parents' and children's emotional wellbeing (which can cause other health issues). The US government ignores the ways in which the children are impacted despite the fact they are US citizens and have been educated and socialized since birth in the United States. ${ }^{58}$ If the children are uprooted from their birth country they must deal with the burden of adjusting to a new culture and living in a new country.

Although ICERD's members have the freedom to deport non-citizens and protect their borders, the United States' deportation practices conflict with ICERD's norms

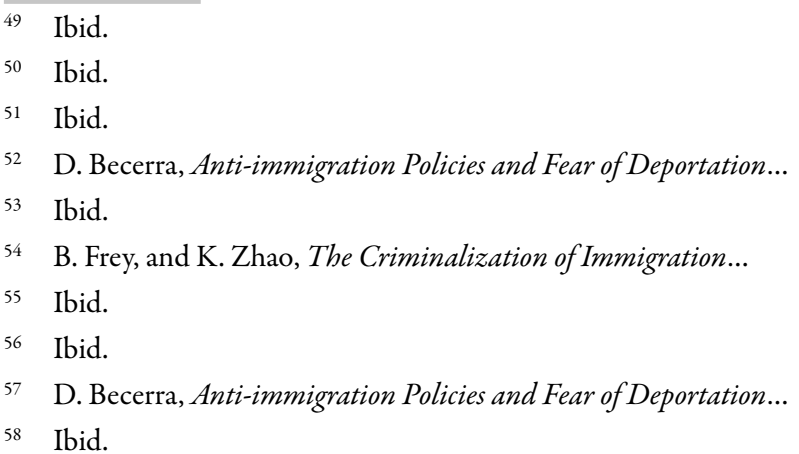


about non-discrimination. ${ }^{59}$ The ICERD committee's most recent report about the United States' lack of compliance with the statute expresses heightened concern about:

- Increased use of racial profiling by local law enforcement agencies to determine immigration status and to enforce immigration laws;

- Increased criminal prosecution for breaches of immigration law;

- Mandatory detention of immigrants for prolonged periods of time;

- Deportation of undocumented immigrants without adequate access to justice. ${ }^{60}$

Overall, the committee chastises the United States' militarization of immigration policies. ${ }^{61}$ ICERD's monitoring body urges the government to abolish Operation Streamline, address any breaches of immigration law through the civil, rather than criminal immigration system, guarantee access to legal representation in all immigration-related matters, and ensure that the rights of non-citizens are fully guaranteed in law and in practice. $^{62}$

\section{SYSTEMATIC VIOLENCE AND PROTECTIONS FROM BODILY HARM}

ICERD prohibits public servants from committing violence against Latino noncitizens and requires its members to provide reparations to victims of such violence. ICERD's Article 5.b requires that state parties must provide non-citizens the right to security of person and protection by the State against violence or bodily harm, whether inflicted by government officials or by any individual group or institution. General Recommendation 30 advises that non-citizens should be provided equal protection and recognition before the law in regard to police brutality. Members to the convention must ensure that all public authorities and public institutions, national and local, do not engage in any act of racial discrimination, and no state shall permit public authorities or public institutions, national or local, to promote or incite racial discrimination. ${ }^{63}$ Non-citizens who are subject to discriminatory violence must be provided access to effective protection and remedies through competent national tribunals and other State institutions.$^{64}$ All people who have been subject to violence are required under ICERD to receive adequate reparation or satisfaction for any damage suffered as a result of such discrimination. ${ }^{65}$ This is reaffirmed in General Recommendation 30, which notes that non-citizens should have access to effective remedies in retribution of the violence as well as just reparation for any damage suffered as a result of such violence.

\footnotetext{
59 B. Frey, and K. Zhao, The Criminalization of Immigration...

60 Committee on the Elimination of Racial Discrimination, "Concluding Observations on the Combined Seventh to Ninth Periodic Reports of the United States of America”, United Nations 2014.

61 Ibid.

62 Ibid.

63 ICERD's Article 2.1.a and Article 4.c.

64 ICERD's Article 6.

65 Ibid.
} 
Recognizing the United States' failure to comply with these obligations, ICERD's monitoring body chastises the government for widespread police brutality and excessive force against Latino non-citizens. ${ }^{66}$ The monitoring body is concerned that, despite the measures taken by the State party to prosecute law enforcement officials for criminal misconduct, impunity for abuses, in particular those committed by the Customs and Border Protection against Hispanic/Latino Americans and undocumented migrants, remains a widespread problem. ${ }^{67}$ The committee also notes with concern that despite the efforts made by the State party to prosecute law enforcement officials for criminal misconduct, impunity of police officers responsible for abuses allegedly remains a widespread problem. ${ }^{68}$ ICERD's monitoring body disapproves of the United States' increasingly militarized approach to immigration law enforcement that leads to the excessive and lethal use of force by [Customs and Border Protection] personnel. ${ }^{69}$

The monitoring body urges the US government to improve its efforts to investigate, prosecute, and punish with appropriate sanctions police brutality and excessive force against Latino non-citizens. ${ }^{70}$ ICERD's committee also expects that investigations are reopened when new evidence becomes available, and that victims or their families are provided with adequate compensation. ${ }^{71}$ ICERD's committee advises the government to comply with the United Nations' 1990 Basic Principles on the Use of Force and Firearms by Law Enforcement Officials, and to ensure the US Customs and Border Protection directive on the use of force is applied and enforced in practice. ${ }^{72}$ Furthermore, the committee finds that the government must improve its reporting process about the excessive use of force and strengthen oversight of, and accountability for, inappropriate use of force..$^{73}$ Finally, the government is prompted to improve its efforts to prevent the excessive use of force by law enforcement officials and to train law enforcement agencies and civil servants to combat discrimination against non-US citizens. ${ }^{74}$

Currently, some police officers (of any gender) tend to practice their duties in a hyper-masculinized manner that is based on police domination of people they encounter. Racial profiling, including in relation to perceived citizenship status, is widespread in police forces. Police internalize stereotypes the media, politicians, and other prominent influencers in their lives propagate, and this impacts the ways in

66 Committee on the Elimination of Racial Discrimination, "Consideration of Reports Submitted by States Parties Under Article 9 of the Convention: Concluding Observations of the Committee on the Elimination of Racial Discrimination: United States of America”, United Nations 2008; Committee on the Elimination of Racial Discrimination, Concluding Observations.

Committee on the Elimination of Racial Discrimination, Concluding Observations.

Committee on the Elimination of Racial Discrimination, Consideration of Reports Submitted by States Parties Under Article 9.

69 Committee on the Elimination of Racial Discrimination, Concluding Observations.

70 Ibid.

71 Ibid.

72 Ibid.

73 Ibid.

74 Ibid.; ICERD's General Recommendation 30. 
which they police as well as if and when they perceive Latino immigrants as criminals and threats that need to be subdued by violence. In order to be hired, police officers must meet prerequisite requirements about body size, upper body strength, and the ability to dominate people physically. ${ }^{75}$ When on active duty officers may perform an aggressive command presence. ${ }^{76}$ However, policing based on problemsolving and negotiation may produce safer environments for both the suspects and the officers. ${ }^{77}$

Moreover, hyper-masculinization of police forces increases the likelihood officers will victimize women and make women feel unsafe and/or humiliated. ICERD's committee criticizes how an epidemic rate of sexual and physical violence is committed against women in the United States. ${ }^{78}$ Gender based violence is especially pervasive among female immigrants. ${ }^{79}$ The expert body chastises the lack of reparation or satisfaction for damages suffered, and gender bias in the legal system and discrimination against women that reduces women's access to remedies and complaint mechanisms. ${ }^{80}$ The expert body condemns the insufficient will of federal and state authorities to take action with regard to such violence and abuse. ${ }^{81}$ In terms of imprisonment of women, the committee draws attention to gendered forms of racial discrimination females encounter. While in detention Latinas may be subject to a multiplicity of oppressions by prison workers, including racism and gender based violence. ${ }^{82}$

ICERD's committee urges the US government to intensify its efforts to combat violence against Latina immigrants. ${ }^{83}$ The government is expected to provide victims with appropriate remedies, adequately fund and set up prevention and early assistance centers, counseling services and temporary shelters, and ensure reports of rape and sexual violence are promptly and thoroughly investigated, [and] that perpetrators are prosecuted and appropriately punished. ${ }^{84}$ Likewise, ICERD's committee advises the government to provide anti-violence-against-women training to those working within the criminal justice system, including police officers, lawyers, prosecutors and judges, and medical personnel. ${ }^{85}$ Moreover, the expert body contends the government must implement information campaigns to raise awareness among women belonging to racial, ethnic and national

\footnotetext{
75 F. Cooper, “Who's the Man?...”

76 Ibid.

77 Ibid.

78 Committee on the Elimination of Racial Discrimination, Concluding Observations.

79 A. Gillespie, Shipping Away the Victims and Passing on the Burdens...

80 ICERD's General Recommendation 25; Committee on the Elimination of Racial Discrimination, Consideration of Reports Submitted by States Parties Under Article 9.

81 Ibid.

82 ICERD's General Recommendation 25.

83 Committee on the Elimination of Racial Discrimination, Concluding Observations.

84 Ibid.; Committee on the Elimination of Racial Discrimination, Consideration of Reports Submitted by States Parties Under Article 9.

Ibid.
} 
minorities about the mechanisms and procedures that are available to seek remedies for violence committed. ${ }^{86}$

Violence against Latina non-citizens is particularly alarming when considering, in some cases, women have immigrated to the United States to flee violence in their country of birth. ${ }^{87}$ In fact, women are vulnerable to violence at all stages of the immigration process. Women entering the United States may be forced into providing sexual services in exchange for safe passage for themselves or their families, or to obtain necessary documentation or other assistance. ${ }^{88}$ When in the United States, Latina noncitizens endure multiple vulnerabilities due to their intersectional identities, which results in hundreds of thousands of Latinas each year being forced into contemporary slavery including forced labor and sex work. ${ }^{89}$ If an immigrant woman is in an abusive relationship with a partner on which she is economically dependent, she may fear being forced to return to her country of birth if she leaves her partner due to her lack of economic resources to remain in the United States. She is also likely to refrain from seeking justice against her abuser if she fears she will be deported if she engages with the police. Women continue to account for the majority of migrants entering host countries under family reunification schemes where if their relationship with an abusive partner ends during the probationary period the women risk deportation. ${ }^{90}$ Aware of this, abusers use this fact to manipulate, control, and intensify abuse against their partners. Fear of deportation if police is contacted prevents many women from escaping abusive relationships. ${ }^{91}$ In a survey among four hundred irregular women migrants in the US, 34\% had experienced domestic violence while only six had ever called the police for help..$^{92}$ If a woman reports violence against her and is deported in the absence of the chief witness the chances of a successful prosecution will be severely limited. The woman's ability to seek any available civil claims will also be frustrated where there has been no opportunity to gather necessary evidence or to seek legal advice. ${ }^{93}$ During the settlement and return process women often suffer new forms of human rights violations and discrimination. ${ }^{94}$ When examining the United States' lack of compliance with ICERD, it is vital to identify the issue from an intersectional perspective in order to assure that advocacy for implementation strategies address the compounded needs of Latina non-citizens.

Ibid.

87 H. Lewis, Transnational Dimensions of Women's Empowerment...

88 A. Edwards, Displacement, Statelessness, and Questions of Gender Equality...

A. Gillespie, Shipping away the Victims and Passing on the Burdens...

90 Ibid.

91 Ibid.

92 Ibid.

93 Ibid.

94 A. Edwards, Displacement, Statelessness, and Questions of Gender Equality... 


\section{CONCLUSION}

The United States deems it is in compliance with ICERD. This publication identifies how the United States does not comply with the human rights treaty regarding the pact's mandates about immigration policies and practices, violent and discriminatory policing, gendered violence, and inequalities in the criminal justice system. It is time to mobilize against such oppression. Communities must collectively draw upon each other's knowledge and skills and work together to dismantle discriminatory policies and practices. Institutional and systematic oppression is most effectively combatted when diverse groups ally together in resistance and collectively promote their visions of rights. It is essential to value diversity within activist communities and to solicit a more robust notion of human rights and to adopt a more robust interpretation of human rights treaties. It is time to resist institutional oppression practiced by the United States in order to restructure the nation to further promote and cherish diversity. After all, we are all human. Don't Latino non-citizens deserve to be treated as such?

\section{BIBLIOGRAPHY}

Agathangelou A., Olwan D., Spira T.L., Turcotte H., "Sexual Divestments from Empire: Women's Studies, Institutional Feelings, and the 'Odious' Machine", Feminist Formations, vol. 27, no. 3 (2015), pp. 139-167, https://doi.org/10.1353/ff.2016.0003.

Alexander M.J., Chandra Talpade M., Cartographies of Knowledge and Power: Transnational Feminism as Radical Praxis, in A. Lock Swarr, R. Nagar (eds.), Critical Transnational Feminist Practice, New York 2010, pp. 23-45.

Becerra D., "Anti-immigration Policies and Fear of Deportation: A Human Rights Issue", Journal of Human Rights and Social Work, vol. 1, no. 1 (2016), pp. 109-119, https://doi. org/10.1007/s41134-016-0018-8.

CERD Task Force, Cidadao Global, Women's HIV Collaborative, Women of Color United, CADRE, Atlanta Public Sector Alliance, Professor Thandabantu Iverson, and Malcolm X Grassroots. From Civil Rights to Human Rights: Implementing US Obligations Under the International Convention on the Elimination of All forms of Racial Discrimination. US Human Rights Network 2010.

Chung E., "The Judicial Enforceability and Legal Effects of Treaty Reservations, Understandings, and Declarations", The Yale Law Journal, vol. 126, no. 170 (2016), pp. 170-224.

Committee on the Elimination of Racial Discrimination, General Recommendation 30 on Discrimination Against Non-Citizens, United Nations 1993.

Committee on the Elimination of Racial Discrimination, General Recommendation 20 on Article 5 of the Convention, United Nations 1996.

Committee on the Elimination of Racial Discrimination, General Recommendation Number 25 on Gender-Related Dimensions of Racial Discrimination, United Nations 2000. 
Committee on the Elimination of Racial Discrimination, General Recommendation 11 on Non-Citizens, United Nations 2005.

Committee on the Elimination of Racial Discrimination, Consideration of Reports Submitted by States Parties Under Article 9 of the Convention: Concluding Observations of the Committee on the Elimination of Racial Discrimination: United States of America, United Nations 2008.

Committee on the Elimination of Racial Discrimination, General Recommendation No. 32: The Meaning and Scope of Special Measures in the International Convention on the Elimination of all Forms Racial Discrimination, United Nations 2009.

Committee on the Elimination of Racial Discrimination, Concluding Observations on the Combined Seventh to Ninth Periodic Reports of the United States of America, United Nations 2014.

Cooper F.R., “'Who's the Man?': Masculinities Studies, Terry Stops, and Police Training”, Columbia Journal of Gender and Law, vol. 18, no. 3 (2008), pp. 671-742.

Edwards A., Displacement, Statelessness, and Questions of Gender Equality and the Convention on the Elimination of All Forms of Discrimination Against Women, 2009, at <http:// www2.ohchr.org/English/bodies/cedaw/docs/UNHCR_CEDAW_Background_ Paper4.pdf $>$.

Frey B., Zhao K., “The Criminalization of Immigration and the International Norm of NonDiscrimination: Deportation and Detention in U.S. Immigration Law", Law and Inequality: A Journal of Theory and Practice, vol. 29, no. 2 (2011), pp. 279-312.

Gillespie A., Shipping Away the Victims and Passing on the Burdens: Can States Continue to Disregard Gender-Based Violence Against Women Migrants on the Basis of Their Immigration Status?, 2008, at <http://s3.amazonaws.com/academia.edu.documents/31719996/ Aoife_Gillespie_LLM_Dissertation.pdf?AWSAccessKeyId=AKIAIWOWYYGZ2Y5 3UL3A\&Expires $=1489723250 \&$ Signature $=$ ArJbV8HuYrR1Ucw 18YpP6HAas\%2FM \%3D\&response-contentdisposition=inline\%3B\%20filename\%3DShipping_Away_the_ Victims_and_Passing_on.Pdf $>$.

Grange M., Majcher I., When Is Immigration Detention Lawful? The Monitoring Practices of UN Human Rights Mechanisms, Global Detention Project 2017, https://doi.org/10.2139/ ssrn.2923038.

Higashida Ch., "Audre Lorde Revisited: Nationalism and Second-Wave Black Feminism”, in eadem (ed.), Black Internationalist Feminism: Women Writers of the Black Left, 1945-1995, 2011, Champaign 2011, https://doi.org/10.5406/illinois/9780252036507.001.0001.

Harris H., "Race Across Borders: The US and ICERD", Harvard Black Letter Law Journal, vol. 24, no. 1 (2008), pp. 61-67.

Herndon L., "Why Is Racial Injustice Still Permitted in the United States? An International Human Rights Perspective on the United States' Inadequate Compliance with the International Convention on the Elimination of all Forms of Racial Discrimination", Wisconsin International Journal of Law, vol. 31, no. 2 (2013), pp. 323-351.

Lake M., Reynolds H., Drawing the Global Colour Line: White Men's Countries and the International Challenge of Racial Equality, New York 2008, https://doi.org/10.1017/ CBO9780511805363. 
Lewis H., Transnational Dimensions of Women's Empowerment: Refocusing on Economic, Social, and Cultural Rights, Northeastern University School of Law: School of Law Faculty Publications 2010, pp. 1-10.

Lugones M., "Heterosexualism and the Colonial/Modern Gender System", Hypatia, vol. 22, no. 1 (2007), pp. 186-209, https://doi.org/10.1353/hyp.2006.0067.

Moravcsik A., The Paradox of US Human Rights Policy, in M. Ignatieff (ed.), American Exceptionalism and Human Rights, Princeton 2005, pp. 147-197, https://doi.org/10.2307/ j.ctt7skx6.8.

Moyn S., The Last Utopia: Human Rights in History, Cambridge 2010.

Primus R., "Equal Protection and Disparate Impact: Round Three", Harvard Law Review, vol. 117, no. 493 (2003), pp. 494-587, https://doi.org/10.2307/3651947.

Texas Department of Housing and Community Affairs et al. v. Inclusive Communities Project, Inc., et al, 576 US. (2015). Supreme Court of the United States.

US Department of State, "Reports Submitted by States Parties Under Article 9 of the Convention", United Nations 2000.

US Department of State, "Committee on the Elimination of Racial Discrimination (CERD) Report”, US Department of State 2017, at <www.state.gov/j/drl/rls/cerd_report/>.

Weitzer R., "White, Black, or Blue Cops? Race and Citizen Assessments of Police Officers", Journal of Criminal Justice, vol. 28, no. 1 (2000), pp. 313-324, https://doi.org/10.1016/ S0047-2352(00)00043-X.

\section{ANNEX A \\ International Convention on the Elimination of All Forms of Racial Discrimination}

\section{The States Parties to this Convention,}

Considering that the Charter of the United Nations is based on the principles of the dignity and equality inherent in all human beings, and that all Member States have pledged themselves to take joint and separate action, in co-operation with the Organization, for the achievement of one of the purposes of the United Nations which is to promote and encourage universal respect for and observance of human rights and fundamental freedoms for all, without distinction as to race, sex, language or religion,

Considering that the Universal Declaration of Human Rights proclaims that all human beings are born free and equal in dignity and rights and that everyone is entitled to all the rights and freedoms set out therein, without distinction of any kind, in particular as to race, colour or national origin,

Considering that all human beings are equal before the law and are entitled to equal protection of the law against any discrimination and against any incitement to discrimination,

Considering that the United Nations has condemned colonialism and all practices of segregation and discrimination associated therewith, in whatever form and wherever they exist, and that the Declaration on the Granting of Independence to 
Colonial Countries and Peoples of 14 December 1960 (General Assembly resolution $1514(\mathrm{XV})$ ) has affirmed and solemnly proclaimed the necessity of bringing them to a speedy and unconditional end,

Considering that the United Nations Declaration on the Elimination of All Forms of Racial Discrimination of 20 November 1963 (General Assembly resolution 1904 (XVIII)) solemnly affirms the necessity of speedily eliminating racial discrimination throughout the world in all its forms and manifestations and of securing understanding of and respect for the dignity of the human person,

Convinced that any doctrine of superiority based on racial differentiation is scientifically false, morally condemnable, socially unjust and dangerous, and that there is no justification for racial discrimination, in theory or in practice, anywhere,

Reaffirming that discrimination between human beings on the grounds of race, colour or ethnic origin is an obstacle to friendly and peaceful relations among nations and is capable of disturbing peace and security among peoples and the harmony of persons living side by side even within one and the same State,

Convinced that the existence of racial barriers is repugnant to the ideals of any human society,

Alarmed by manifestations of racial discrimination still in evidence in some areas of the world and by governmental policies based on racial superiority or hatred, such as policies of apartheid, segregation or separation,

Resolved to adopt all necessary measures for speedily eliminating racial discrimination in all its forms and manifestations, and to prevent and combat racist doctrines and practices in order to promote understanding between races and to build an international community free from all forms of racial segregation and racial discrimination,

Bearing in mind the Convention concerning Discrimination in respect of Employment and Occupation adopted by the International Labour Organisation in 1958, and the Convention against Discrimination in Education adopted by the United Nations Educational, Scientific and Cultural Organization in 1960,

Desiring to implement the principles embodied in the United Nations Declaration on the Elimination of el Forms of Racial Discrimination and to secure the earliest adoption of practical measures to that end,

Have agreed as follows:

\section{PART I}

\section{Article 1}

1. In this Convention, the term "racial discrimination" shall mean any distinction, exclusion, restriction or preference based on race, colour, descent, or national or ethnic origin which has the purpose or effect of nullifying or impairing the recognition, enjoyment or exercise, on an equal footing, of human rights and fundamental freedoms in the political, economic, social, cultural or any other field of public life.

2. This Convention shall not apply to distinctions, exclusions, restrictions or preferences made by a State Party to this Convention between citizens and non-citizens. 
3. Nothing in this Convention may be interpreted as affecting in any way the legal provisions of States Parties concerning nationality, citizenship or naturalization, provided that such provisions do not discriminate against any particular nationality.

4. Special measures taken for the sole purpose of securing adequate advancement of certain racial or ethnic groups or individuals requiring such protection as may be necessary in order to ensure such groups or individuals equal enjoyment or exercise of human rights and fundamental freedoms shall not be deemed racial discrimination, provided, however, that such measures do not, as a consequence, lead to the maintenance of separate rights for different racial groups and that they shall not be continued after the objectives for which they were taken have been achieved.

\section{Article 2}

1. States Parties condemn racial discrimination and undertake to pursue by all appropriate means and without delay a policy of eliminating racial discrimination in all its forms and promoting understanding among all races, and, to this end:

(a) Each State Party undertakes to engage in no act or practice of racial discrimination against persons, groups of persons or institutions and to en sure that all public authorities and public institutions, national and local, shall act in conformity with this obligation;

(b) Each State Party undertakes not to sponsor, defend or support racial discrimination by any persons or organizations;

(c) Each State Party shall take effective measures to review governmental, national and local policies, and to amend, rescind or nullify any laws and regulations which have the effect of creating or perpetuating racial discrimination wherever it exists;

(d) Each State Party shall prohibit and bring to an end, by all appropriate means, including legislation as required by circumstances, racial discrimination by any persons, group or organization;

(e) Each State Party undertakes to encourage, where appropriate, integrationist multiracial organizations and movements and other means of eliminating barriers between races, and to discourage anything which tends to strengthen racial division.

2. States Parties shall, when the circumstances so warrant, take, in the social, economic, cultural and other fields, special and concrete measures to ensure the adequate development and protection of certain racial groups or individuals belonging to them, for the purpose of guaranteeing them the full and equal enjoyment of human rights and fundamental freedoms. These measures shall in no case en tail as a con sequence the maintenance of unequal or separate rights for different racial groups after the objectives for which they were taken have been achieved.

\section{Article 3}

States Parties particularly condemn racial segregation and apartheid and undertake to prevent, prohibit and eradicate all practices of this nature in territories under their jurisdiction. 


\section{Article 4}

States Parties condemn all propaganda and all organizations which are based on ideas or theories of superiority of one race or group of persons of one colour or ethnic origin, or which attempt to justify or promote racial hatred and discrimination in any form, and undertake to adopt immediate and positive measures designed to eradicate all incitement to, or acts of, such discrimination and, to this end, with due regard to the principles embodied in the Universal Declaration of Human Rights and the rights expressly set forth in article 5 of this Convention, inter alia:

(a) Shall declare an offence punishable by law all dissemination of ideas based on racial superiority or hatred, incitement to racial discrimination, as well as all acts of violence or incitement to such acts against any race or group of persons of another colour or ethnic origin, and also the provision of any assistance to racist activities, including the financing thereof;

(b) Shall declare illegal and prohibit organizations, and also organized and all other propaganda activities, which promote and incite racial discrimination, and shall recognize participation in such organizations or activities as an offence punishable by law;

(c) Shall not permit public authorities or public institutions, national or local, to promote or incite racial discrimination.

\section{Article 5}

In compliance with the fundamental obligations laid down in article 2 of this Convention, States Parties undertake to prohibit and to eliminate racial discrimination in all its forms and to guarantee the right of everyone, without distinction as to race, colour, or national or ethnic origin, to equality before the law, notably in the enjoyment of the following rights:

(a) The right to equal treatment before the tribunals and all other organs administering justice;

(b) The right to security of person and protection by the State against violence or bodily harm, whether inflicted by government officials or by any individual group or institution;

(c) Political rights, in particular the right to participate in elections-to vote and to stand for election-on the basis of universal and equal suffrage, to take part in the Government as well as in the conduct of public affairs at any level and to have equal access to public service;

(d) Other civil rights, in particular:

(i) The right to freedom of movement and residence within the border of the State;

(ii) The right to leave any country, including one's own, and to return to one's country;

(iii) The right to nationality;

(iv) The right to marriage and choice of spouse;

(v) The right to own property alone as well as in association with others;

(vi) The right to inherit;

(vii) The right to freedom of thought, conscience and religion; 
(viii) The right to freedom of opinion and expression;

(ix) The right to freedom of peaceful assembly and association;

(e) Economic, social and cultural rights, in particular:

(i) The rights to work, to free choice of employment, to just and favourable conditions of work, to protection against unemployment, to equal pay for equal work, to just and favourable remuneration;

(ii) The right to form and join trade unions;

(iii) The right to housing;

(iv) The right to public health, medical care, social security and social services;

(v) The right to education and training;

(vi) The right to equal participation in cultural activities;

(f) The right of access to any place or service intended for use by the general public, such as transport hotels, restaurants, cafes, theatres and parks.

\section{Article 6}

States Parties shall assure to everyone within their jurisdiction effective protection and remedies, through the competent national tribunals and other State institutions, against any acts of racial discrimination which violate his human rights and fundamental freedoms contrary to this Convention, as well as the right to seek from such tribunals just and adequate reparation or satisfaction for any damage suffered as a result of such discrimination.

\section{Article 7}

States Parties undertake to adopt immediate and effective measures, particularly in the fields of teaching, education, culture and information, with a view to combating prejudices which lead to racial discrimination and to promoting understanding, tolerance and friendship among nations and racial or ethnical groups, as well as to propagating the purposes and principles of the Charter of the United Nations, the Universal Declaration of Human Rights, the United Nations Declaration on the Elimination of All Forms of Racial Discrimination, and this Convention. 
Malia Lee WOMACK - UC Berkeley (BA), Columbia University (MA), The Ohio State University (MA, PhD). Main research interests: transnational feminisms and critical human rights, neoliberalism, universalism, and globalization, feminist theory and critical race theory, collective identities, identity, and intersectionality, US imperialism and exceptionalism, Latin American Studies and Puerto Rican Studies. Major publications: "US Colonialism in Puerto Rico: Why Intersectionality Must be Addressed in Reproductive Rights" (Oxford's St. Anthony's International Review [STAIR], vol. 16, no. 1 [2020], pp. 74-85), "The Tentacles of Neoliberalism: How the Master's Tools Became a Vehicle for Activism" (Journal of Research on Women and Gender, vol. 8, no. 1 [2017], pp. 36-48), "Puerto Rican Nationhood and the Diverse Nature of Collective Identity Construction" (Journal of Politics and Democratization, vol. 2, no. 2 [2017], pp. 37-41), "The United States' International Valuing of Anti-Racism Norms Over Gender Equality Norms", in V. Demos, M. Segal (eds.), Advances in Gender Research: Gender Panic, Gender Policy, Vol 24, Bingley 2017, pp. 273-307. 